\title{
EDUCATIONAL CHALLENGES OF E-LEARNING IN SPORT MAJORING HIGHER EDUCATION INSTITUTIONS
}

\author{
Danica Pirsl ${ }^{1}$ \\ Andon Kostadinovic ${ }^{2}$
}

DOI: https://doi.org/10.31410/ERAZ.2019.309

\begin{abstract}
Domain-specific cognitive competencies refer to generic skills, more specific to e-learning competencies in Physical education (PE) students over their academic lifespan. When higher education standards benchmark students' competence development, they relate to all educational stages. E-learning in sports sciences in Serbia is still being developed and is attracting attention of wider educational arena. Faculty of Physical Education and Sport in Nis wanted to contribute more to this area trying to diminish limiting influence of technical and cultural factors. Therefore, the University of Nis and National Sports Academy established distance learning centers for sports sciences to promote e-learning and higher-level diploma attainment. This, in itself, poses educational and economic challenges as well. This paper presents problems, advantages and drawbacks of this IPA Cross-Border cooperation project, how after one-year joint distance learning centers in Serbia and Bulgaria for sports sciences were accredited, and how students benefited from it in the labor market thus meeting economic challenges of introducing distance learning mode of instruction. However, the objective of this paper is not only to describe learning environment and assessment of learning outcomes, but also to emphasize e-learning specific teaching methods and perceived and realistically acquired skills and abilities. Sports sciences courses at the Faculty of Sport in Nis aim to develop generic and sports specific skills. The underlying theory used is Sloan-C Five Pillars managing the quality of online education, its effects, students' satisfaction, teaching staff commitment, price and investment returns, and access. They encompass: 1) mode of learning, 2) integration manner, 3) forms of learning content and objectives delivery, 4) variety of sports sciences teaching methods, 5) participation of learning subjects, and 6) place of teaching method execution. 81\% employers' satisfaction survey results point to the justification of introducing the e-learning mode in sports sciences at the Faculty of sport and physical education in Nis, Serbia.
\end{abstract}

Keywords: E-learning, distance learning centers, educational challenges, generic and sports specific skills, labor market challenges.

\section{INTRODUCTION}

Competitiveness promotes quality, and that is good for students. However, universities and higher education institutions need more operative freedom and appropriate funding in order to enter competition. Introducing new, different curricula will stimulate competitiveness. A fair competition will attract students from abroad. Competitiveness and collaboration do not exclude each other. Competitiveness, first of all, means academic quality and not just commercialization. Europe should try to become the kind of education space that would attract the best students from all over the world. However, this calls for a swift elimination of a number or inadequate laws to enhance labor market competition [1].

Specific measures proposed in Europe are: a) introduction of study programs taught in languages spoken worldwide, b) better marketing strategies in non-European countries, c) development of adequate services for foreign students to make them feel comfortable in European education institutions, d) being on par with other universities through strategic networking [7], [8].

\footnotetext{
$1 \quad$ University of Nis, Faculty of Sport, Nis, Serbia

2 University of Nikola Tesla, Faculty of Law, Management and Security „Constantine the Great”, Nis, Serbia
} 
We cannot expect our students with their current competencies to be competitive in the world labor market. The same way as universities and higher education institutions must follow the laws of the labor market to survive the competition so must our students. Thus, generic competencies, social intelligence and specifically e-learning competencies of our students such as the capacity for analysis and synthesis, the capacity for applying knowledge in practice, basic general knowledge in the field of study, information management skills, interpersonal skills, the ability to work autonomously, elementary computer skills, research skills [2] must be developed along with all the other education related competencies.

\section{ORGANIZATION CAPABILITIES}

Organizations in general need to acquire capabilities and competences in order to enter new product/market areas [16]. HEIs will therefore as well need to acquire new capabilities and competences to engage in e-learning because new skills are required [14]. Focus of many studies is on examining e-learning in higher education which are increasingly adopting this distance learning mode and at the same time posing question: what competencies and capabilities are required by HEIs engaging in e-learning? A definition and categorization of e-learning allows the description of e-learning by usage in terms of pedagogy, by timing in terms of synchronous or asynchronous, and by place in terms of distance of students: either face-to-face or distant.

The term capabilities refer to an organization's capacity to deploy resources using organizational processes [15]. Collis [17] divided capabilities into three categories of possible sources of organizational heterogeneity. First, those with an ability to perform basic functional activities of the organization, such as marketing, or brand management or operational excellence [18]. HEI such as those offering majoring sports sciences studies have recognized the need to enhance their offer as branding exercise and health promoting sciences as their main marketing entice. Second, those responsible for dynamic improvements to the organization, such as product innovation, the ability of the organization to learn and adapt, or flexibility in product development. While introduced first in 2014 as a result of the IPA project enabling the University of Nis and National Sports Academy to establish distance learning centers for sports sciences, both HEIs grabbed this way a chance to promote e-learning in their respective schooling systems and thus offer the international students' population a possibility of higher-level diploma attainment. Third category represents "more metaphysical strategic insights that enable firms to recognize the intrinsic value of other resources or to develop novel strategies before competitors" [17].

Knowing that distance learning mode is being increasingly used in higher education in Serbia, Faculty of sport in Nis strived to enter and stay in the distance learning market by widening their offer not just in Bachelor applied degree but also in Master studies cycle in sports sciences. To make it more attractive the Faculty joins forces with National Sports Academy in Sofia, Bulgaria, and creates mutual exercise and sports related sciences curricula offered to everybody interested in pursuing not just sports career but intending to obtain a valuable internationally recognized degree. Insisting on product innovation and the ability of the organization to learn and adapt and show flexibility in product development Faculty of sport introduced into the Masters study curricula as one of the most competitive products widely relevant and sought for area of Adaptive Physical Education [10], [11]. Thus, the Faculty has in short time become internationally recognized for its content relevant and broad scope inclusive Master degree of physical education and sport with specific reference in Adaptive Physical Education. 
In the ongoing accreditation cycle Faculty of sport in Nis has applied to implement doctoral studies cycle in sports sciences in English language hoping to thus attract the international students and, in this way, increase their revenue and competitiveness on the market. This endeavor is not an easy task since all major cities in Serbia have for long established sports studies within their respective universities, namely in Belgrade, Novi Sad, Nis. A medium sized town Nis is putting all possible efforts to improve already existing e-learning, or better to say blended learning modes of distance learning. The result of such efforts is in the best possible way reflected in the fact that the Faculty of sport in Nis is now ranked between 150th and 200th place in the Academy Ranking of World Faculties list in the area of sports. With this significant progress, Faculty of Sport and Physical Education in Nis became the leading faculty in the region of Southeast Europe, finding itself far ahead of the faculties in Belgrade and Novi Sad, who held their position between 200th and 300th place this year.

\section{EDUCATIONAL CHALLENGES - SOFT SKILLS}

In recent leadership surveys, the number one leadership challenge cited by participants was developing management and people skills in technically-oriented people [3]. Although many professionals possess domain specific, they might have difficulty communicating this to others and motivating employees to achieve best results. Many things can create communication ,gaps" [12]. Effective interpersonal communication involves a lot more than just the words we use. When we are face-to -face, nonverbal communication is the source of much of the information transmitted. When estimating and recommending educational related skills and competencies we usually apply Soft Skills List - with important sub-elements: Communication Styles, Teamwork, Leadership Skills, Effective \& Excellent Customer Service, Decision Making \& Problem Solving, Managing Time and Pressures, Self-Management \& Attitude. The term Soft Skills is a broad topic. Below are some sample categories that might be applicable for any team and any profession, sports jobs not being an exception [6] [4].

1. Communication

- Presentation skills,

- Spoken communication,

- Difficult conversations,

- Professional writing,

- Effective email writing.

2. Teamwork

- Inter-team cooperation,

- Intra-team cooperation,

- Diversity,

- Productivity,

- Goal setting and action.

3. Leadership Skills

- Empowerment,

- Planning,

- Confidence in leaders,

- Vision \& direction,

- Supervision,

- Coaching and/or mentoring.

4. Effective \& Excellent Customer Service

- Communication with the customer, including challenging conversations, 
- Setting and resetting customer expectations,

- Delighting the customer,

- Building customer confidence,

- A consistently winning customer experience,

- Growing the customer relationship,

- Opportunity management,

- A Team approach to meeting the customer's needs.

5. Decision Making \& Problem Solving

- Creativity,

- Flexibility,

- Team problem solving.

6. Managing Time and Pressures

- Change,

- Time management,

- Effective meetings.

7. Self-Management \& Attitude

- Stress management,

- Positive attitude and influence,

- Initiative,

- Concern and compassion for others [9].

We have to rely on the feedback of employers in the area of sport business. There was a comprehensive survey assessing the opinions of the region wide employers in sports business, posted on a web site of the Faculty of sport in Nis, showing overall satisfaction with our graduate students scoring high $81 \%$ satisfaction with their competence and domain specific knowledge in sport and physical education. However, they emphasized the need to install more and brush up their existing soft skills, since, it turned out our graduates are most frequently elected in the manager's position in primary and secondary schools, university settings and local community authorities. Thus, our graduates refer back to the faculty citing necessary requirements for better and more successful job finding in our still transitive economy. This is vital since the teachers when passing down specific knowledge and competencies also have to adapt learning communication skills throughout educational stages in specific distance learning mode study.

\section{CONCLUSION}

It is obvious that complex job of e-learning based study programs in sports implementation requires the management attention in that (sport) students need to fulfill different web-based tasks and communicate them between their peers and teachers as well [11]. All the more important aspect of creating fully communicative persons in their respective profiles of studies turned to be interesting for further studies since students have to pass their final exams not web based but direct in person at the premises of the faculty. Thus, whatever content was posted on the Moodle platform now has to be communicated in real life situations, face to face with respective course teachers.

Our question about the significance of social competencies throughout life span was also validated through a survey within students both in bachelor applied and master sports and physical education study programs. A list of attributes or characteristic traits for prospective employees was drawn up and it starts with empathy - the ability to understand someone else's feelings 
and re-experience them so one can actively listen to what others say, the second ranked was appreciation- one can understand and appreciate others' views, the third ranked was focus on attaining the goal or task without conflict, and the fourth ranked was understanding emotional boundaries. Thus, it was proved time and again that organizational awareness implies knowing how to do things within the organization, understand client and vendor organizations, and act with the client's best interest in mind.

\section{REFERENCES}

[1] Baines, A. (1994). „Negotiate to Win”, Work Study, Vol. 43, 8, pp. 25-26.

[2] Weinert, F., and Kluwe, R. (eds.). (1987). Metacognition, Motivation, and Understanding, Erlbaum, Hillsdale, NJ, pp. 21-29.

[3] P. Drucker. (1998). The Coming of the New Organization. Knowledge Management, USA: Harvard Business School Press.

[4] H. Holec, (1987). "The learner as manager: managing learning or managing to learn?" In Wenden and Rubin (Eds.). Learner strategies in Language Learning, Prentice hall international: UK Ltd.

[5] I. Nonaka. (1998). The Knowledge-Creating Organization, Knowledge Management, USA: Harvard School Press.

[6] K. A. Ericsson, N. Charness, P. J. Feltovich, \& R. R. Hoffman (Eds.) (2006). Cambridge Handbook of Expertise and Expert Performance. New York, NY: Cambridge University Press, Studies of expertise from psychological perspectives.

https://www.researchgate.net/publication/200772882_Studies_of_expertise_from_psychological_perspectives [accessed Jan 08 2019].

[7] http://www.atctraining.com/soft_skills_definition_of_communication.htm

[8] Mayer Committee. Putting general education to work: The key competencies report. AEC/ MOVEET, Melbourne, 1992.

[9] P. Kearns. (2001). Generic Skills for the New Economy. Australia: NCVER.

[10] Pirsl. D., Pirsl, T. Ljajic, S. (2019). Communication and soft skills of hybrid sports science distance learning mode students, XXV conference: Trends of development "Quality of higher education", pp. 1-4.

[11] S. Weinert, S. Ebert, \& M. Dubowy. (2010). Kompetenzen und soziale Disparitäten im Vorschulalter. Zeitschrift für Grundschulforschung, 1, pp. 32-45.

[12] J. Wirth, \& Klieme. (2002). Computer literacy im Vergleich zwischen Nationen, Schulformen und Geschlechtern. Unterrichtswissenschaft, 30, pp. 136-157.

[13] Hamel, G., \& Heene, A. (1994). Competency Based Competition. Chichester: John Wiley \& Sons Ltd.

[14] Salmon, G. (2000). Computer Mediated Conferencing for Management Learning at the Open University. Management Learning, 31(4), pp. 491-502.

[15] Amit, R., \& Schoemaker, P. J. H. (1993). Strategic assets and organizational rent. Strategic Management Journal, 14(1), pp. 33-46.

[16] Walsh, S. T., \& Linton, J. D. (2001). The Competence Pyramid: A Framework for Identifying and Analyzing Firm and Industry Competence. Technology Analysis \& Strategic Management, 13(2), pp. 165-178.

[17] Collis, D. J. (1994). Research Note: How Valuable Are Organizational Capabilities? Strategic Management Journal, 15 (Special Issue: Competitive Organizational Behavior), pp. 143-152.

[18] Treacy, M., \& Wiersema, F. (1993). Customer intimacy and other value disciplines. Harvard Business Review, 71, pp. 84-93. 